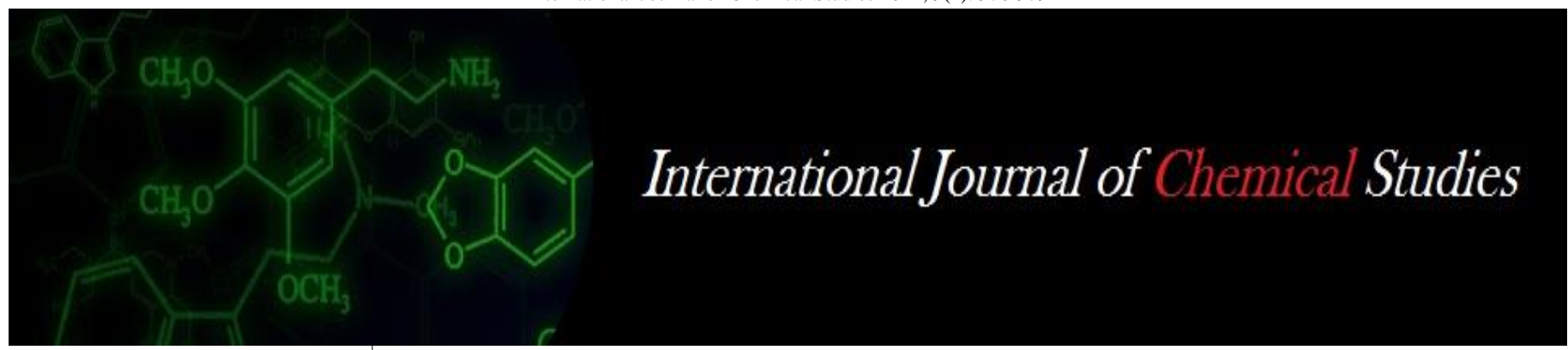

P-ISSN: 2349-8528

E-ISSN: 2321-4902

www.chemijournal.com

IJCS 2021; 9(1): 976-979

(C) 2021 IJCS

Received: 09-10-2020

Accepted: 18-11-2020

Tejashvini A

Department of Soil Science and Agricultural Chemistry, UAS,

GKVK, Bangalore, Karnataka, India

Subbarayappa CT

Department of Soil Science and Agricultural Chemistry, UAS, GKVK, Bangalore, Karnataka, India

Corresponding Author:

Tejashvini A

Department of Soil Science and Agricultural Chemistry, UAS,

GKVK, Bangalore, Karnataka, India

\section{Interactive effect of calcium and boron on growth, yield and nutrient uptake by tomato (Lycopersicon esculentum $\mathrm{L}$.)}

\section{Tejashvini A and Subbarayappa CT}

DOI: https://doi.org/10.22271/chemi.2021.v9.i1n.11351

\begin{abstract}
A field experiment was carried out to know the effect of calcium and boron on the growth and yield of tomato (Lycopersicon esculentum L.) in kharif 2018-19. Three levels of Ca and B were applied through burnt lime $\left(0,5\right.$ and $\left.10 \mathrm{~kg} \mathrm{ha}^{-1}\right)$ and borax $\left(0,1.1\right.$ and $\left.2.2 \mathrm{~kg} \mathrm{ha}^{-1}\right)$ along with RDF and FYM. The study was conducted in Randomized Complete Block Design (RCBD) with 2-factors each at three levels and repeated thrice. Application of calcium @ $10 \mathrm{~kg} \mathrm{ha}^{-1}$ significantly increased plant height $(146.52 \mathrm{~cm})$, number of primary branches (11.18), number of fruits per plant (51.78) and fruit yield (44.52 $\left.\mathrm{t} \mathrm{ha}^{-1}\right)$. Application of B @ $2.2 \mathrm{~kg} \mathrm{ha}^{-1}$ increased plant height $(143.85 \mathrm{~cm})$, number of primary branches (11.06), number of fruits per plant (49.06) and fruit yield (43.57 $\left.\mathrm{t} \mathrm{ha}^{-1}\right)$. The interaction between $\mathrm{Ca}$ and $\mathrm{B}$ did not show statistically significant differences.
\end{abstract}

Keywords: Tomato, calcium, boron, yield

\section{Introduction}

Tomato (Lycopersicon esculentum L.) is a common vegetable crop (Srividya et al., 2014) ${ }^{[18]}$ and a good source of vitamin $\mathrm{A}$ and $\mathrm{C}, \mathrm{Ca}, \mathrm{Fe}$, protein, antioxidants and carotenoids (Di Masico et al., 1989) ${ }^{[7]}$ which helps to prevent cancer and degenerative diseases (Giovannucci, 1999) ${ }^{[9]}$. In addition to cultivation and cultural traditions, the yield of tomato crop is also limited by many biotic and abiotic factors (Ali, 2014). Management of nutrients is important for optimizing crop yield improving fruit quality and increasing profitability (Ganeshamurthy et al., 2011) ${ }^{[8]}$. Therefore, the use of vital nutrients increases nutrient uptake and use (Phillips et al., 2004) ${ }^{[14]}$ and decreases conditions associated with nutrient deficiency. The essential secondary $(\mathrm{Ca})$ and micronutrients (B) are required for growth and development of tomato. Nevertheless, $\mathrm{Ca}$ and $\mathrm{B}$ uptake and their use in plants are very limited in agriculture.

In contrast, insufficient $\mathrm{Ca}$ in plants leads to break down of cell wall and membranes, susceptibility to a variety of diseases, physiological disorders and post-harvest problems especially in fresh produce. Deficiency is seen as browning and dieback of the leaves in rising tips. With newly emerging leaves sticking together at the edges, leaves curl and margins turn brown, leaving extended leaves shredded at their margins. Blossom end rot is probably the most recognized symptom of Ca deficiency in tomatoes.

Boron is a minor element and plants vary widely in terms of their requirements; the spectrum of levels of deficiency and toxicity are narrow. Its widespread deficiency (Gupta et al., 1985) ${ }^{[11]}$ can cause serious yield reduction and uneven ripening of tomato fruit (Adams, 1978) ${ }^{[2]}$. Taking into account the current research work was undertaken to evaluate the effect of $\mathrm{Ca}$ and $\mathrm{B}$ on growth and yield of tomato and to elucidate the interactive effect of $\mathrm{Ca}$ and $\mathrm{B}$ on vegetative and reproductive growth.

\section{Material and Methods}

A field experiment entitled "Interactive effect of calcium and boron on growth, yield and nutrient uptake by tomato (Lycopersicon esculentum L.)" was conducted in Kuduragere village, northern transect of Bengaluru by taking tomato as test crop in kharif 2018-19. The experimental site was situated at $13.1833^{\circ} \mathrm{N}$ latitude and $77.6011^{\circ} \mathrm{E}$ longitude. The experiment comprised three levels of calcium supplied through burnt lime $(\mathrm{CaO})$ viz., 0,5 and 
$10 \mathrm{~kg} \mathrm{ha}^{-1}$ and $0,1.1$ and $2.2 \mathrm{~kg} \mathrm{ha}^{-1}$ of boron through borax on tomato crop (Hybrid: Rishika). The experiment was laid out in Randomized Complete Block Design with Factorial concept (F-RCBD) which was replicated thrice. The recommended dose of fertilizers viz., 250:250:250 kg ha-1 of $\mathrm{N}, \mathrm{P}_{2} \mathrm{O}_{5}, \mathrm{~K}_{2} \mathrm{O}$ was applied through urea, SSP and MOP to all the treatments except control one week after transplanting to avoid transplanting shock. Along with $\mathrm{N}, \mathrm{P}, \mathrm{K}, \mathrm{Ca}$ and $\mathrm{B}$ were applied through burnt lime and borax at different levels as per treatment details at the time of fertilizer application. Seedlings were produced in pro-trays containing coco-peat as potting mixture. After 20 days of sowing, healthy plants were transplanted to main field.

The soil sample was analysed for initial nutrient status. The texture of the soil was sandy loam with an acidic pH of 5.37. The soil was low in organic carbon $\left(4.6 \mathrm{~g} \mathrm{~kg}^{-1}\right)$ medium in available nitrogen $\left(280.83 \mathrm{~kg} \mathrm{ha}^{-1}\right)$ and phosphorus $(35.07 \mathrm{~kg}$ $\mathrm{ha}^{-1}$ ), high in potassium (253.81 $\mathrm{kg} \mathrm{ha}^{-1}$ ) and deficient in exchangeable calcium and available boron $\left(1.39 \mathrm{meq} 100 \mathrm{~g}^{-1}\right.$ \& $0.31 \mathrm{mg} \mathrm{kg}^{-1}$, respectively).

At the harvest, leaf sample was collected and analyzed for different nutrient content. Meanwhile, fruit samples were collected at harvest stage subjected for processing. Both leaf and fruit samples were washed with tap water and then with distilled water. The specimens were air-dried first and then oven-dried at $65{ }^{\circ} \mathrm{C}$ (Robinson et al., 1986) ${ }^{[16]}$. The dried samples were powdered and used for analysis of $\mathrm{Ca}$ and $\mathrm{B}$ by standard analytical methods. Uptake was calculated by multiplying nutrient content with dry matter yield. The total uptake was calculated by combining the uptake of plant and fruit.

The recorded data on different parameters were statistically analyzed based on the procedure given by Gomez and Gomez (1984) ${ }^{[10]}$. Critical differences were worked out at 5 per cent probability level where the treatments differed significantly.

\section{Results and Discussion \\ Effect of calcium and boron application on growth and yield of tomato crop}

The calcium and boron levels had shown significant difference among the treatments on growth and yield parameters and it is presented in Table 1.

\section{Growth parameters}

Significantly higher plant height and number of branches (146.52 $\mathrm{cm} \& 11.18)$ was recorded with the application of calcium $10 \mathrm{~kg} \mathrm{ha}^{-1}$ along with RDF + FYM $\left(\mathrm{Ca}_{2}\right)$ compared to no calcium application $\left(\mathrm{Ca}_{0}\right)$ which recorded $127.85 \mathrm{~cm}$ and 7.93. However, it was on par with the application of calcium 5 $\mathrm{kg} \mathrm{ha}^{-1}$ along with RDF + FYM $\left(\mathrm{Ca}_{1}\right)$ which recorded 141.81 $\mathrm{cm}$ and 10.66, respectively. Calcium might have influenced the plant height at all the growth stages. It might be due to the uptake of nutrients from the soil and its utilization in plants. This finding corroborates with the results of Abdur and Ihsan (2012) ${ }^{[1]}$ in tomato.

Significantly higher plant height and number of branches were recorded with the application of boron at $2.2 \mathrm{~kg} \mathrm{ha}^{-1}$ along with RDF + FYM (143.85 cm \& 11.06, respectively) followed by $1.1 \mathrm{~kg} \mathrm{ha}^{-1}$ boron along with RDF + FYM (139.89 $\mathrm{cm} \& 9.86$, respectively) compared to no boron application (132.44 $\mathrm{cm} \& 8.84$, respectively). The study revealed that the growth attributes increased with the application of $2.2 \mathrm{~kg} \mathrm{ha}^{-1} \mathrm{~B}$ through borax. An increase in the plant height and number of branches in the present study may be due to association of boron with the development of cell wall and cell differentiation and hence, helps in root elongation and shoot growth. Similar findings were also reported by Basavarajeshwari et al., $2007^{[5]}$.

The interaction was found statistically non-significant among the treatments combination. Significantly lower plant height and number of branches was recorded in $T_{1}(91.40 \mathrm{~cm} \& 5.63$, respectively) as compared with other treatments. Significantly higher plant height and number of branches of $151.22 \mathrm{~cm}$ and 12.40 were recorded in $\mathrm{T}_{10}\left(\mathrm{Ca} @ 10 \mathrm{~kg} \mathrm{ha}^{-1}+\mathrm{B} @ 2.2 \mathrm{~kg} \mathrm{ha}^{-}\right.$ ${ }^{1}+\mathrm{RDF}+\mathrm{FYM}$ ) followed by application of Ca @ $10 \mathrm{~kg} \mathrm{ha}^{-1}$ + B @ $1.1 \mathrm{~kg} \mathrm{ha}^{-1}$ + RDF + FYM (147.22 cm \& 11.13, respectively) compared to control. Highest plant height might be due to the supply of nutrients by FYM along with mineral fertilizers as compared to control as it received no input application. Thus $\mathrm{Ca}+\mathrm{B}$ combination was proved more effective in producing taller plants, more branches per plant and high leaf number which were in accordance with the results of Rab and Haq (2012) ${ }^{[15]}$.

\section{Yield parameters}

Yield is a complex character which involves many intrinsic and external variables interacting. In addition to many environmental factors to which plants are exposed during the growing season, this depends largely on the development and mobilization of carbohydrates, water absorption and soil nutrients (Schonfeld et al., 1988) ${ }^{[17]}$. In addition to enhanced cultivars, the nutrient management system plays a key role in yield improvement. In addition to enhanced cultivars, the nutrient management system plays a key role in yield improvement. The tomato yield data showed a large yield variation due to different levels of application of $\mathrm{Ca}$ and $\mathrm{B}$.

Among the calcium levels number of fruits per plant and fruit yield was recorded significantly higher with $\left(\mathrm{Ca}_{2}\right) 10 \mathrm{~kg} \mathrm{ha}^{-1}$ of calcium along with RDF + FYM (51.78 \& $\left.44.52 \mathrm{t} \mathrm{ha}^{-1}\right)$ followed by $5 \mathrm{~kg} \mathrm{ha}^{-1}$ of Ca along with RDF + FYM (48.97 \& $\left.43.90 \mathrm{t} \mathrm{ha}^{-1}\right)$ compared to no calcium $\left(\mathrm{Ca}_{0}\right)$ application $(36.86$ \& $\left.40.08 \mathrm{t} \mathrm{ha}^{-1}\right)$. The $\mathrm{Ca}$ might have increased the various enzyme activities in the plant tissue, which is responsible for enhanced flower initiation, ultimately increasing the number of fruits per plant. The number of fruits per plant depends on the number of flowers and the ability of the plant to provide the nutrients required for growth and development. These findings are in accordance with previous studies of Meena $(2015)^{[13]}$ in tomato.

Among the boron levels, significantly higher number of fruits per plant and fruit yield was recorded with $\left(\mathrm{B}_{2}\right)$ application of boron at $2.2 \mathrm{~kg} \mathrm{ha}^{-1}$ along with RDF + FYM (49.06 \& 43.57t $\left.\mathrm{ha}^{-1}\right)$, which was on par with $\mathrm{B}_{1}$ which received $1.1 \mathrm{~kg} \mathrm{ha}^{-1} \mathrm{~B}$ along with RDF + FYM (46.12 \& $\left.43.14 \mathrm{t} \mathrm{ha}^{-1}\right)$ compared to no application of boron $\left(42.42 \& 41.78 \mathrm{t} \mathrm{ha}^{-1}\right)$. Boron raises the stigma's sugar level and assists in the fruit set by facilitating the development of the pollen tube along with the germination of pollen. Boron influences carbohydrate metabolism (Haque et al., 2011) ${ }^{[12]}$ and increases the supply of carbohydrates for the formation of tomato flowers and fruit and decreases flower abscission. Thus the number of fruits per plant increased with the application of boron.

The interaction was found statistically non-significant. However, among treatment combinations, significantly lower number of fruits per plant and fruit yield was recorded in $\mathrm{T}_{1}$ (26.45 \& $28.45 \mathrm{t} \mathrm{ha}^{-1}$, respectively) without any input application. Whereas, significantly higher number of fruits per plant and fruit yield were recorded with application of $\mathrm{Ca}$ @ $10 \mathrm{~kg} \mathrm{ha}^{-1}+\mathrm{B} @ 2.2 \mathrm{~kg} \mathrm{ha}^{-1}+\mathrm{RDF}+\mathrm{FYM}$ (56.33 \& 45.00 $\mathrm{t} \mathrm{ha}^{-1}$, respectively) followed by application of Ca@10 kg ha 
${ }^{1}+$ B @ $1.1 \mathrm{~kg} \mathrm{ha}^{-1}+\mathrm{RDF}+\mathrm{FYM}$ (53.30\& $44.85 \mathrm{t} \mathrm{ha}^{-1}$, respectively compared to control. Higher fruit number might be due to the addition of organic manure along with mineral fertilizers which help in improving fruit number compared with $\mathrm{T}_{1}$ (Absolute control).

\section{Effect of calcium and boron application on calcium and boron uptake}

Among the calcium levels total uptake of calcium was recorded significantly higher with $\mathrm{Ca}_{2}\left(66.28 \mathrm{~kg} \mathrm{ha}^{-1}\right)$ and $\mathrm{Ca}_{1}$ (53.52 $\mathrm{kg} \mathrm{ha}^{-1}$ ) compared to $\mathrm{Ca}_{0}\left(38.62 \mathrm{~kg} \mathrm{ha}^{-1}\right)$ in rural. Application of higher level of $\mathrm{Ca}$ helped in maximum uptake of calcium as compared to no calcium (Subbiah and Rani, 1994) ${ }^{[19]}$. However, boron uptake was not influenced significantly by the application of calcium (Table 2).

Among the boron levels, there was non-significant difference between calcium uptake by crop at harvest. However, uptake of boron was significantly influenced by the application of boron. The higher boron uptake of $135.04 \mathrm{mg} \mathrm{kg}^{-1}$ was recorded with the application of boron at $2.2 \mathrm{~kg} \mathrm{ha}^{-1}$ along with RDF + FYM $\left(\mathrm{B}_{2}\right)$ and was on par with the application of boron $\left(\mathrm{B}_{1}\right)$ at $1.1 \mathrm{~kg} \mathrm{ha}^{-1}$ along with RDF + FYM (112.65 mg $\left.\mathrm{kg}^{-1}\right)$ compared with $\mathrm{B}_{0}(\mathrm{RDF}+\mathrm{FYM}$ without $\mathrm{B})$ which recorded lowest total boron uptake of $91.52 \mathrm{mg} \mathrm{kg}^{-1}$ (Table 2). Boron application along with FYM resulted in accumulation of boron. The increased $B$ content and dry matter accumulation in plants also resulted in higher uptake of boron (Akteruzzaman et al., 2012) ${ }^{[3]}$.

The interaction was found statistically non-significant. Among the treatment combinations, total calcium and boron uptake by tomato plant varied significantly as compared to control. Significantly lower values of $16.71 \mathrm{~kg} \mathrm{ha}^{-1}$ and 53.01 $\mathrm{mg} \mathrm{kg}^{-1}$, were recorded respectively in $\mathrm{T}_{1}$ might be due to lack of input fertilizers which resulted in less uptake of nutrients (Davis et al., 2003) ${ }^{[6]}$. However, significantly higher total calcium and boron uptake was recorded with application of Ca@ $10 \mathrm{~kg} \mathrm{ha}^{-1}+\mathrm{B} @ 2.2 \mathrm{~kg} \mathrm{ha}^{-1} \mathrm{~B}$ along with RDF + FYM (70.89 kg ha' \& $140.61 \mathrm{mg} \mathrm{kg}^{-1}$, respectively). This might be due to the addition of inputs through mineral fertilizers along with FYM which helped in increasing the nutrient content of plant compared to $\mathrm{T}_{1}$ (Fig 1).

Table 1: Effect of calcium and boron on growth and yield parameters of tomato plant

\begin{tabular}{|c|c|c|c|c|}
\hline \multirow{2}{*}{ Treatment details } & \multicolumn{2}{|c|}{ Growth parameters } & \multicolumn{2}{|c|}{ Yield parameters } \\
\hline & Plant height $(\mathrm{cm})$ & No. of primary branches & No. of fruits per plant & Fruit yield (t ha-1) \\
\hline $\mathrm{Ca} 0$ & 127.85 & 7.93 & 36.86 & 40.08 \\
\hline $\mathrm{Ca}_{1}$ & 141.81 & 10.66 & 48.97 & 43.90 \\
\hline $\mathrm{Ca}_{2}$ & 146.52 & 11.18 & 51.78 & 44.52 \\
\hline S.Em \pm & 2.61 & 0.33 & 1.17 & 0.87 \\
\hline $\operatorname{LSD}(\mathrm{p}=0.05)$ & 7.63 & 0.96 & 3.43 & 2.53 \\
\hline $\mathrm{B}_{0}$ & 132.44 & 8.84 & 42.42 & 41.78 \\
\hline $\mathrm{B}_{1}$ & 139.89 & 9.86 & 46.12 & 43.14 \\
\hline $\mathrm{B}_{2}$ & 143.85 & 11.06 & 49.06 & 43.57 \\
\hline S.Em \pm & 2.61 & 0.33 & 1.17 & 0.87 \\
\hline $\operatorname{LSD}(\mathrm{p}=0.05)$ & 7.63 & 0.96 & 3.43 & $\mathrm{NS}$ \\
\hline \multicolumn{5}{|c|}{$\mathrm{Ca} \times \mathrm{B}$} \\
\hline S.Em \pm & 4.53 & 0.57 & 2.03 & 1.50 \\
\hline LSD $(p=0.05)$ & $\mathrm{NS}$ & NS & NS & NS \\
\hline \multicolumn{5}{|c|}{ Treatment combinations } \\
\hline $\mathrm{T}_{1}$-Absolute control & 91.40 & 5.63 & 26.45 & 28.45 \\
\hline $\mathrm{T}_{2}-\mathrm{Ca}_{0} \mathrm{~B}_{0}+\mathrm{RDF}+\mathrm{FYM}$ & 119.22 & 6.97 & 35.97 & 38.30 \\
\hline $\mathrm{T}_{3}-\mathrm{Ca}_{0} \mathrm{~B}_{1}+\mathrm{RDF}+\mathrm{FYM}$ & 129.22 & 7.80 & 36.17 & 40.55 \\
\hline $\mathrm{T}_{4}-\mathrm{Ca}_{0} \mathrm{~B}_{2}+\mathrm{RDF}+\mathrm{FYM}$ & 135.11 & 9.02 & 38.45 & 41.37 \\
\hline $\mathrm{T}_{5}-\mathrm{Ca}_{1} \mathrm{~B}_{0}+\mathrm{RDF}+\mathrm{FYM}$ & 137.00 & 9.57 & 45.60 & 43.33 \\
\hline $\mathrm{T}_{6}-\mathrm{Ca}_{1} \mathrm{~B}_{1}+\mathrm{RDF}+\mathrm{FYM}$ & 143.22 & 10.63 & 48.90 & 44.03 \\
\hline $\mathrm{T}_{7}-\mathrm{Ca}_{1} \mathrm{~B}_{2}+\mathrm{RDF}+\mathrm{FYM}$ & 145.22 & 11.77 & 52.40 & 44.32 \\
\hline $\mathrm{T}_{8}-\mathrm{Ca}_{2} \mathrm{~B}_{0}+\mathrm{RDF}+\mathrm{FYM}$ & 141.11 & 10.00 & 45.70 & 43.70 \\
\hline $\mathrm{T}_{9}-\mathrm{Ca}_{2} \mathrm{~B}_{1}+\mathrm{RDF}+\mathrm{FYM}$ & 147.22 & 11.13 & 53.30 & 44.85 \\
\hline $\mathrm{T}_{10-} \mathrm{Ca}_{2} \mathrm{~B}_{2}+\mathrm{RDF}+\mathrm{FYM}$ & 151.22 & 12.40 & 56.33 & 45.00 \\
\hline S.E.m \pm & 4.30 & 0.54 & 2.05 & 1.45 \\
\hline $\operatorname{LSD}(\mathrm{p}=0.05)$ & 12.78 & 1.61 & 6.09 & 4.32 \\
\hline
\end{tabular}

Table 2: Effect of calcium and boron on calcium and boron uptake

\begin{tabular}{|c|c|c|}
\hline Treatment details & Ca uptake & B uptake \\
\hline $\mathrm{Ca}_{0}$ & 38.62 & 99.04 \\
\hline $\mathrm{Ca}_{1}$ & 53.52 & 118.43 \\
\hline $\mathrm{Ca} 2$ & 66.28 & 121.74 \\
\hline S.E.m \pm & 2.73 & 7.15 \\
\hline $\operatorname{LSD}(\mathrm{p}=0.05)$ & 7.95 & NS \\
\hline $\mathrm{B}_{0}$ & 48.05 & 91.52 \\
\hline $\mathrm{B}_{1}$ & 53.36 & 112.65 \\
\hline $\mathrm{B}_{2}$ & 57.01 & 135.04 \\
\hline S.E.m \pm & 2.73 & 7.15 \\
\hline $\operatorname{LSD}(\mathrm{p}=0.05)$ & $\mathrm{NS}$ & 20.87 \\
\hline \multicolumn{3}{|c|}{$\mathrm{Ca} \times \mathrm{B}$} \\
\hline S.E.m \pm & 4.72 & 12.38 \\
\hline LSD $(p=0.05)$ & NS & NS \\
\hline
\end{tabular}




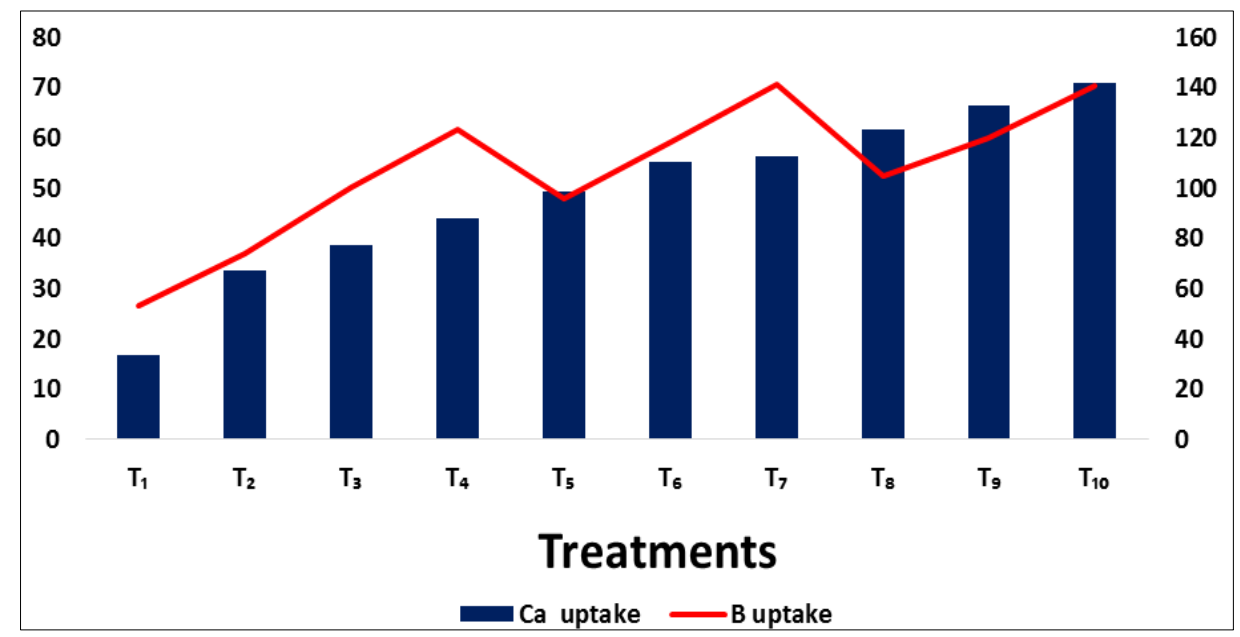

Fig 1: Impact of $\mathrm{Ca}$ and $\mathrm{B}$ application on $\mathrm{Ca}$ and $\mathrm{B}$ uptake by tomato plant

\section{Conclusion}

Application of calcium and boron alone and in combination improved the growth, yield and nutrient uptake when compared with absolute control. Application of $10 \mathrm{~kg} \mathrm{ha}^{-1}$ of $\mathrm{Ca}$ and $2.2 \mathrm{~kg} \mathrm{ha}^{-1}$ of $\mathrm{B}$ along with $\mathrm{RDF}$ and FYM significantly increased growth and yield parameters compared with other treatments.

\section{References}

1. Abdur R, Ihsan H. Foliar application of calcium chloride and borax influences plant growth, yield, and quality of tomato (Lycopersicon esculentum Mill.) fruit. Turky J Agric 2012;36:695-701.

2. Adams P. Tomatoes in peat. Part 1. How feed variations affect yield. Grower 1978;89:1091, 1093-1094.

3. Akteruzzaman MA, Syed S, Akram RC. Foliar application of some macro and micronutrients improves tomato growth, flowering and yield. Int. J Biosci 2012;3(10):280-287.

4. Ali S, Riaz KA, Mairaj G, Arif M, Fida M, Bibi S. Assessment of different crop nutrient management practices for yield improvement. Aust. J Crop Sci 2008;2(3):150-157.

5. Basavarajeshwari CRM, Patil PS, Hosamani BH, Ajjappalavara Naik, Smitha RP, Ukkund KC. Effect of Foliar Application of Micronutrients on Growth and Yield components of Tomato (Lycopersicon esculentum Mill.), Kar. J Agric. Sci 2007;21(3):428-430.

6. Davis JM, Sanders DC, Lengnick L, Sperry W. Boron improves the growth, yield, quality and nutrient content of tomato. J Amer. Soc. Hort. Sci 2003;128:441-446.

7. DI-Masico P, Kaiser S, Sies H. Lycopene as the most efficient biological carotenoid singlet oxygen quencher. Arch. Biochem. Biophys 1989;274:532-8. https://doi.org/10.1016/0003- 9861(89)90467-0.

8. Ganeshamurthy AN, Satisha GC, Prakash P. Potassium nutrition on yield and quality of fruit crops with special emphasis on banana and grapes. Karnataka J Agric. Sci 2011;24:29-38.

9. Giovannucci E. Tomatoes, tomatoes-based products, lycopene and cancer: Review of epidemiologic literature. J Natl. Cancer Inst 1999;91:317-331. https://doi.org/10.1093/jnci/91.15.1331A

10. Gomez KA, Gomez AA. Statistical procedures for agricultural research (2 ed.). John wiley and sons, NewYork 1984, 680.
11. Gupta UC, Cutcliffe JA. Boron nutrition of carrots and table beets grown in a boron deficient soil. Commun. Soil Sci. Plant. Anal 1985;16:509-511.

12. Haque ME. Effect of nitrogen and boron on the growth and yield of tomato. Msc (Agri) thesis, Department of Soil Science, Sher-E-Bangla Agricultural University, Dhaka-1207 2011.

13. Meena DC, Maji S, Meena Govind JK, Kumawat R, Meena KR, Kumar S et al. Improvement of growth, yield and quality of tomato (Solanum lycopersicum L.) cv. Azad T-6 with foliar application of zinc and boron. Int. J Bio-resource Stress Management 2015;6(5):598-601.

14. Phillips AL, Barry C, Giovannoni J. Signal transduction systems regulating fruit ripening. Trends Plant Sci 2004;9:331-338. doi.org/10.1016/j.tplants.2004.05.004.

15. Rab A, Haq I. Foliar application of calcium chloride and borax influences plant growth, yield, and quality of tomato (Lycopersicon esculentum L.) fruit. Tur. J Agric. Fores 2012;36:695701.

16. Robinson D. Compensatory changes in the partitioning of dry matter in relation to nitrogen uptake and optimal variations in growth. Annals of Botany 1986;58:841-848.

17. Schonfeld MA, Johnson RC, Carver BF, Mornhinweg DW. Water relations in winter wheat as drought resistance indicator. Crop Sci 1988;28:526-531.

18. Srividya S, Reddy SS, Sudhavani V, Reddy R. Effect of post-harvest chemicals on fruit physiology and shelf Life of tomato under ambient conditions. Int. J Agric. Food Sci. Technol 2014;5(2):99-104.

19. Subbiah K, Rani P. Foliar nutrition in crops: A review. Madras Agric. J 1994;81:299-302. 